\title{
Chemical Screening and Antimicrobial Activities of Rwandan traditional medicinal plant, Urtica massaica Mildbr (Urticaceae)
}

\author{
Maniriho $\mathrm{O}^{1 *}$, Nkurunziza $\mathrm{JP}^{2}$, Ayodele $\mathrm{AE}^{1}{ }^{3}$, , Benimana $\mathrm{F}^{4}$, Murhula $\mathrm{HP}^{1}$, Farhan $\mathrm{HFA}^{1}$, Nimbeshaho $\mathrm{F}^{1}, \mathrm{Cyiza} \mathrm{F}^{5}$ \\ ${ }^{1}$ Department of Pharmacognosy, Medicinal Plants Research and Drug Development Programme, Pan African \\ University/University of Ibadan, Ibadan, Nigeria \\ ${ }^{2}$ Department of Chemistry, School of Sciences, College of Science and Technology, University of Rwanda, Rwanda \\ ${ }^{3}$ Department of Botany, Faculty of Science, University of Ibadan, Ibadan, Nigeria \\ ${ }^{4}$ Department of Food and Biotechnology, Faculty of Medical Biology, South Ural State University, Chelyabinsk, Russia \\ ${ }^{5}$ Department of chemistry, University of Bandung, Indonesia
}

Article History
Received: 21.02 .2021
Accepted: 26.03 .2021
Published: 27.04 .2021
Journal homepage:
https://www.easpublisher.com

Abstract : Chemical screening and antimicrobial activities of stems and roots of Rwandan Urtica massaica Mildbr. (Urticaceae) were investigated. Chemical screening revealed that majority of bioactive secondary metabolites was present at higher concentration in stem than in root. Antimicrobial activities of both stem and root bark methanolic extracts, SBME and RBME, were followed by Agar Disc diffusion and Broth Macro-dilution methods; Inhibition zones, Minimum Inhibition Concentration, MIC and Minimum Bactericidal Concentration, MBC; against the tested microbial strains. Values of inhibition zone for SBME against $E$. coli were $21.667 \pm 1.529$ to $28.000 \pm 2.851 \mathrm{~mm}$. RBME inhibited $E$. coli from $19.667 \pm 1.734$ to $25.667 \pm 1.023 \mathrm{~mm}$. Salmonella sp were fully resistant to RBME. SBME inhibited Salmonella sp from $7.167 \pm 0.208$ to $24.067 \pm 2.503 \mathrm{~mm}$ but inhibited $S$. aureus from $17.333 \pm 1.335$ to $21.667 \pm 0.334 \mathrm{~mm}$. RBME against $S$. aureus showed $15.000 \pm 0.578,17.000 \pm 0.578$ and $20.667 \pm 0.334 \mathrm{~mm}$ inhibition zones respectively. MIC values of SBME were $6.250 \pm 1.562 \mathrm{mg} / \mathrm{mL}$ (E. coli), $10.156 \pm 4.752 \mathrm{mg} / \mathrm{mL}$ (Salmonella $\mathrm{sp}$ ) and $6.250 \pm 1.563 \mathrm{mg} / \mathrm{mL}$ (S. aureus). MIC of RBME were $7.813 \pm 1.563 \mathrm{mg} / \mathrm{mL}$ (E. coli) and $7.813 \pm 1.563 \mathrm{mg} / \mathrm{mL}$ (S. aureus) though it was found inactive against Salmonella sp. MBC values of SBME were $12.500 \pm 3.125 \mathrm{mg} / \mathrm{mL}$ (E. coli), $19.531 \pm 10.156 \mathrm{mg} / \mathrm{mL}$ (Salmonella $\mathrm{sp})$ and $12.500 \pm 3.125 \mathrm{mg} / \mathrm{mL}$ (S. aureus). MBC values of RBME were $15.625 \pm 3.125 \mathrm{mg} / \mathrm{mL}$ (E. coli) and $15.625 \pm 3.125 \mathrm{mg} / \mathrm{mL}$ (S. aureus). The results indicated greater antimicrobial activities of stem than root of $U$. massaica, thus corroborating with the fact that majority of bioactive phytochemicals were highly present in SBME than in RBME. U. massaica stem should be considered as natural antimicrobial potential to treat infectious diseases.

Keywords: Urtica massaica stem, root, phytochemical screening, bioactive phytoconstituents and antimicrobial activities.

Copyright ( ) 2021 The Author(s): This is an open-access article distributed under the terms of the Creative Commons Attribution 4.0 International License (CC BY-NC 4.0) which permits unrestricted use, distribution, and reproduction in any medium for non-commercial use provided the original author and source are credited.

\section{INTRODUCTION}

Medicinal plants have been used in traditional health care systems since prehistoric times and are still the most important health care source for the most of the world's population. The World Health Organization (WHO) has estimated that more than $75 \%$ of the world's total population depends on herbal drugs for their primary healthcare needs [1]. Pathogenic microorganisms absolutely infect human and develop infectious diseases [2]. A variety of microorganisms threaten a human health. The ability of humans to control and prevent infectious diseases is continuously challenged due to the enormous diversity of microbial pathogens combined with their ability to evolve and adapt to changing environment [3]. The most common bacterial pathogens which cause infectious diseases include Escherichia coli, Salmonella spp., Aeromonas spp., Pseudomonas spp., Streptococcus pyogenes, Klebsiella spp., and Staphylococcus aureus etc $[4,5]$.

The use of medicinal plants in the treatment of infectious diseases is an old age practice; and several natural products derived from plants are used for treatment of numerous human diseases for thousands of years. Medicinal plants are used in many parts of the world as healing for variety of human ailments [6]. The traditional use of plant for the treatment of infectious diseases remain the most affordable and easily accessible source of treatment particularly in the primary healthcare systems of developing countries [7]. All parts of a plant can be 
utilized for medication purpose like roots, bark, woody stems, leaves, flowers, fruits, resin and seeds. For many species, different parts of the same plant are used to produce different remedies for various diseases [8].

In the case of Urtica massaica Mildbr. (Urticaceae), Rwandan traditional medicine practitioners use its stem and root alone and/or in mixtures with other plant species to treat numerous ailments including bruises, fractures, venereal diseases, stomach problems, skin infections, bladder complications, cough and headache [9, 10-11].

Considering the Rwandan traditional medicinal uses of this plant, the objective of this work was to screen the phytoconstituents and investigate antibacterial activities of Urtica massaica stem and root barks.

\section{Materials and Methods \\ 2.1 Chemical reagents}

All reagents and chemicals utilised in this work were of analytical grade (ANALAR).

\subsection{Collection of plant materials and Herbarium authentication}

The stem and root barks of Urtica massaica were collected from the wild areas surrounding Volcanoes National Park of Rwanda (VNPR) of Karambi village/Bugarama cell/Kabatwa sector/Nyabihu District, Northern Province, Rwanda. The area's geographical coordinates taken by GPS (at $3 \mathrm{~m}$ of accuracy) were Latitude: $\left(\mathrm{S} 01^{0} 34.351^{0}\right.$ and $\left.\mathrm{E} 029^{0} 25.495^{\circ}\right) ; \quad\left(\mathrm{S}_{01} 1^{0} 34.401^{\circ}\right.$ and $\left.\mathrm{E} 029^{0} 25.480^{\circ}\right)$; $\left(\mathrm{S}_{0} 1^{0} 34.365^{\circ}\right.$ and $\left.\mathrm{E} 029^{0} 25.696^{\circ}\right)$ and Altitude: $2362 \mathrm{~m}$. The pressed plant sample was identified and authenticated by Professor Elias BIZURU, a professional botanist at National Herbarium of Rwanda. The specimen was kept under the collector's collection, M.O 1(Maniriho Olivier 1), and preserved for future reference and other identification issues.

\subsection{Plant material handling and Extraction procedures}

The collected stem and root barks of Urtica massaica were garbed, washed with distilled water to remove any insect materials, clay and mud, chopped and then air-dried at room temperature. Dried plant materials were mechanically ground using pestle and mortar. The two grinding machines (RETSCH SM100 and RETSCH SM200, Germany) were later used to obtain the desired powder size. The obtained dry powder was then weighed and stored in airtight polyethylene containers.

The crude extract of air-dry powdered stem and root barks of Urtica massaica was prepared by cold maceration using $80 \%$ methanol as an extracting solvent. This was prepared by weighing 270 grams of coarsely powdered plant materials (stem and root barks separately) using sensitive digital analytical balance (AHAUS Corp. Pine Brook NJ, USA) and soaked in a clean flask containing methanol $(80 \%)$ in distilled water.

It was then kept for a period of seven days accompanied with intermittent shaking using mini orbital shaker. The entire mixture was filtered through a funnel plunged with muslin cloth two times. The remaining residue or marc was re-macerated twice for a total of six days with a fresh methanol. The marc was then pressed, and the resulting solution after successive filtration was evaporated using a rotary evaporator set at $40^{\circ} \mathrm{C}$ to remove the solvent methanol. Finally, the concentrated root bark and stem bark methanol extracts (RBME and SBME) were placed in an oven at $37-40^{\circ} \mathrm{C}$ until completely dried and solidified.

The dried powder of extracts was weighed in air tight container and then kept in dark place in refrigerator $(0-4)^{0} \mathrm{C}$ for further analyses.

\subsection{Phytochemical screening}

In this work, the qualitative phytochemical investigations of the crude extracts of Urtica massaica stem and root barks were carried out using the following standard tests as described in research documents [12-14].

\subsubsection{Alkaloids}

About $0.5 \mathrm{~g}$ of extract were stirred with $5 \mathrm{~mL}$ of $1 \%$ aqueous hydrochloric acid on a water bath; $1 \mathrm{~mL}$ of the filtrate was then treated (into separate test tubes) with few drops of Dragendorf's reagent, Wagner's reagent, and Tannic acid test (tannic acid solution) respectively.

The formation of a Reddish Brown precipitate, Yellow precipitate and Brownish precipitate respectively indicated the presence of alkaloids.

\subsubsection{Sterols and Steroids}

To $0.5 \mathrm{~g}$ of extract in $2 \mathrm{~mL}$ distilled water was added $1 \mathrm{~mL}$ of acetic anhydride. 2-3drops of Conc. $\mathrm{H}_{2} \mathrm{SO}_{4}$ were added. The coloration of deep green color indicated the presence of Steroids (LiebermannBurchard Test).

About $0.5 \mathrm{~g}$ of extract was dissolved in $2 \mathrm{ml}$ of chloroform and $2 \mathrm{ml}$ of concentrated sulphuric acid was added from the side of the test tube. Test tube was shaken for few minutes. The development of red colour in chloroform layer (lower layer) and greenish-yellow in acid layer (upper layer) indicated the presence of sterols (Salkowaski test). 


\subsubsection{Terpenoids}

To 5mg of extract and each solvent fraction, add $5 \mathrm{~mL}$ of acetic anhydride and 2-3 drops of conc. $\mathrm{H}_{2} \mathrm{SO}_{4}$. A deep red coloration was a positive test for Terpenoids.

\subsubsection{Glycosides}

To $5 \mathrm{mg}$ of extract, and each solvent fraction as well, dissolved $5 \mathrm{~mL}$ distilled water was added aqueous $\mathrm{NaOH}(20 \%)$. Formation of Yellow colour showed the positive test for Glycosides.

\subsubsection{Flavonoids}

General Test: To $0.2 \mathrm{~g}$ of the extract were added $5 \mathrm{ml}$ of ethanol and 3 drops of $\mathrm{feCl}_{3}$. A dark green colour indicated the presence of flavonoids.

Shinoda Test: To $5 \mathrm{mg}$ of extract was added 12 magnesium turnings and 1-2 drops of concentrated $\mathrm{HCl}$ was added. Formation of a pink colour testified the presence of flavonoids.

\subsubsection{Anthocyanins}

To $0.2 \mathrm{~g}$ of extract was added $2 \mathrm{~mL}$ of distilled water and warmed for 5 minutes and allowed to cool. Then $2 \mathrm{~mL}$ of $20 \% \mathrm{HCl}$ were added and observed for colouration. On addition of $2 \mathrm{~mL} \mathrm{NH}_{4} \mathrm{OH}$ solution, the pinkish red colouration which turned to bluish violet is indicative of the presence of anthrocyanins.

\subsubsection{Coumarins}

To $0.02 \mathrm{~g}$ of extract was added $2 \mathrm{~mL}$ of distilled water and warmed for 5 minutes and allowed to cool. Then, $2 \mathrm{~mL}$ of $10 \% \mathrm{NaOH}$ was added to the aqueous extract. The formation of yellow color indicated the presence of coumarins.

\subsubsection{Phenols/Tannins}

Ferric Chloride Test: Crude extract $0.5 \mathrm{~g}$ was added to $20 \mathrm{~mL}$ distilled water by boiling for 10 minutes and filtered while hot. It was then allowed to cool and $1 \mathrm{~mL} \mathrm{FeCl}_{3}$ reagent (5\%) added to the filtrate. An intense colouration ranging from Blue-Black, Green or Blue-Green indicated the presence of phenols and tannins.

Lead acetate Test: To $10 \mathrm{mg}$ of extract is added $1 \mathrm{~mL}$ of $1 \%$ Lead acetate solution. The formation of precipitate indicated the presence of tannins and phenolic compounds.

\subsubsection{Saponins}

Foam Test: Extract $(1 \mathrm{mg})$ is diluted with 20 $\mathrm{mL}$ distilled water. This is well shaken in a graduated cylinder for 10 minutes. The formation of foam to a length of $1 \mathrm{~mL}$ is indicative of the presence of saponins.

\subsection{Evaluation of Antimicrobial activity \\ 2.5.1 Culture media and microorganisms}

Mueller Hinton Agar (MHA), Mueller Hinton Broth (MHB), Blood Agar Base (BA Base) and Manitol
Salt Agar Base (MSA) manufactured by Himedia Laboratories (Mumbai, India) were used for bacterial cultivation.

Following the manufacturer's guidelines with some modification, all bacterial media preparation and inoculum standardization were accordingly performed [15].

The test bacterial strains were clinical isolates and were kindly provided by the Department of clinical research and training, University Teaching Hospital (CHUB), Butare, Rwanda. These were Staphylococcus aureus and Streptococcus pyogenes (Gram positive) and E. coli, Salmonella sp, Klebsiella pneumonia, Acinetobacter sp and Proteus morganis (Gram negative). The standard antibiotic discs used as positive

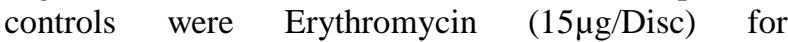

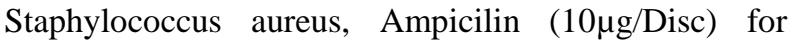
Streptococcus pyogenes, Ciprofloxacin $(5 \mu \mathrm{g} / \mathrm{Disc})$ for E. coli, Salmonella sp, Klebsiella pneumonia, Proteus morganis and Acinetobacter sp. The standards discs were manufactured by BioLab Inc., Budapest, Hungary.

\subsubsection{Sterility proofing of the extracts}

The method by Mounyr [16] was modified to check the sterility of the extracts. About $2 \mathrm{~mL}$ of the extract were put into $10 \mathrm{ml}$ of Muller Hinton broth then incubated at $37^{\circ} \mathrm{C}$ for 24 hours. The clearness or absence of turbidity of the broth after incubation signified that the extracts were sterile.

\subsubsection{Susceptibility testing and determination of zone of inhibition}

Agar disc diffusion method was used for susceptibility testing and determining zone of inhibition of plant extracts against test microorganisms [17]. Three different concentrations $(150 \mathrm{mg} / \mathrm{mL}, \quad 300$ $\mathrm{mg} / \mathrm{mL}$, and $600 \mathrm{mg} / \mathrm{mL}$ ) for each extracts (RBME and SBME) were prepared by dissolving $150 \mathrm{mg}, 300 \mathrm{mg}$, and $600 \mathrm{mg}$ of extract with $1 \mathrm{~mL}$ of their respective $20 \%$ dimethyl sulfoxide DMSO [18].

Thirty microlitres $(30 \mu \mathrm{L})$ of each of three final concentrations for each extract was then used to impregnate the sterilized $6 \mathrm{~mm}$ blank discs (Whatman $\mathrm{N}^{\mathrm{o}} 1$ filter paper). Dimethyl sulfoxide-loaded discs were used as negative controls for both extracts RBME and SBME accordingly. All impregnated discs were ensured to be fully dried at room temperature in a bio-safety cabinet hood for a time prior to the application on bacterial lawn. The impregnated discs with plant extracts were manually placed on the completely dried inoculated Agar by using sterile forceps. The discs were pressed gently to ensure uniform contact with agar surface. Furthermore, No more than nine disks (including negative and positive control discs) were placed on a $100 \mathrm{~mm}$ Petri-plate for ensuring about equidistance to each other to avoid overlapping of inhibition zone $[17,19]$. 
Then, the Petri-plates were inverted and placed undisturbed in a bio-safety cabinet at room temperature for 2 hours. Finally, they were incubated for 24 hours at $35 \pm 2{ }^{\circ} \mathrm{C}[16]$.

The inhibition zone's diameter around either the treated discs or the control discs was measured for the sensitivity of the investigated bacteria to the plant crude extracts. Their diameters were measured to the nearest whole millimeter as judged by a naked eye using a ruler. All tests were carried out three times to ensure the reliability, and the average of the three replicates for each extract and control discs were calculated [19].

Hence, complete zone of inhibition was measured in millimeter for extracts and antibiotic standard discs. The mean zone of inhibition and standard error of the mean (Mean \pm SEM) was calculated for methanol extracts and standard discs as well.

The scale of measurement was (disc diameter included): $\geq 20 \mathrm{~mm}$ : zone of inhibition is strongly inhibitory; < 20-7mm: zone of inhibition is moderately/mildly inhibitory; and $<7 \mathrm{~mm}$ means no inhibitory [20].

\subsubsection{Determination of Minimum Inhibitory Concentration (MIC) \\ MIC was determined by Broth Macro-Dilution} Method [16, 21]. The stock concentration $600 \mathrm{mg} / \mathrm{mL}$ was prepared by weighing $3600 \mathrm{mg}$ of extract (RBME and SBME) and dissolving in $6 \mathrm{~mL}$ of $20 \%$ DMSO. Two-fold serial dilution procedure was performed by transferring $1 \mathrm{~mL}$ of extract concentration from stock into three $1^{\text {st }}$ tubes of the three rows of ten tubes each already containing $1 \mathrm{~mL}$ of sterilized liquid growth medium. Two-fold serial dilutions were set up with 300 , $150,75,37.5,18.75,9.375,4.688,2.344,1.172$ and $0.586 \mathrm{mg} / \mathrm{mL}$ in descending order from column number $1\left(1^{\text {st }}\right.$ column $)$ to column number $10\left(10^{\text {th }}\right.$ column $)$ of the three rows. $1 \mathrm{~mL}$ of the standardized bacterial suspension was added to each tube resulting in recommended final cell count of about $5 \times 105$ $\mathrm{CFU} / \mathrm{mL}$. Three additional tubes each one at the end of each row were used as: the first for sterility proofing of extract (tube containing growth medium and Extract), the second for Negative Control (tube containing growth medium, Solvent and particular bacterial isolate suspension) and the third for Positive Bacterial Growth Control (tube containing growth medium and particular bacterial isolate suspension). All the tubes were incubated overnight (for 24 hours) at $37^{\circ} \mathrm{C}$ in an incubator (Binder BF $260 \mathrm{GmH}$, Tuttingen, Germany).

On the next day, by comparing with the tube of Positive Bacterial Growth Control, the lowest concentration of extract dilution showing no macroscopical growth (absence of turbidity) of a test microorganism was recorded as the MIC value of the extract. Absence of turbidity in sterility control tube indicated the absence of contaminants in extracts. Negative control tube showed that the solvent had no impact on the tested organism growth. The tests were performed in triplicate in aseptic conditions for each test organism.

\subsubsection{Determination of Minimum Bactericidal Concentration (MBC)}

MBC of the plant extracts on the tested microorganisms was performed according to method highlighted in Clinical Laboratory Standards Institute's document M26-A [15] and research work by Mounyr [16]. Briefly, a loop full of samples from all test tubes that showed no visible growth of bacteria in MIC assay was sub-cultured into antibiotic free agar medium in incubator at $37{ }^{\circ} \mathrm{C}$ for $18-24$ hours. After incubation period, the least concentration of the plant extract which killed $99.9 \%$ of the colony formation was recorded as MBC value of the extract. Triplicate tests were accordingly carried out in aseptic conditions [16].

\section{RESUlTS AND DiscUSSIONS 3.1 Chemical screening}

Preliminary chemical screening of crude extracts (RBME and SBME) of U. massaica revealed the presence of different phytochemical compounds that are summarized in table 1 .

RBME contained Alkaloids (high concentration), Coumarins (high concentration), Saponins (moderate concentration), Anthocyanins (moderate concentration), Terpenoids (low concentration), Phenols and Tannins (low concentration), Flavonoids (low concentration). Phytosterols, Steroids and Glycosides are absent in RBME.

In SBME, phytochemical components like Saponins, Phenols and Tannins, Flavonoids, Phytosterols and Steroids were present in high concentration. Those in moderate concentration were Glycosides and Terpenoids while Coumarins and Alkaloids were present in low concentration. Only Anthocyanins were absent in SBME. 
Table-1: Phytochemical constituents in crude extracts of Urtica massaica (RBME and SBME)

\begin{tabular}{|c|c|c|c|c|}
\hline $\begin{array}{l}\text { Phytochemical } \\
\text { components }\end{array}$ & Chemical screening tests & $\begin{array}{ll}\begin{array}{l}\text { Positive } \\
\text { confirmation sign }\end{array} & \text { test } \\
\end{array}$ & RBME & SBME \\
\hline \multirow[t]{3}{*}{ Alkaloids } & Dragendorf's test & $\begin{array}{l}\text { Reddish-brown } \\
\text { precipitate }\end{array}$ & +++ & + \\
\hline & Tannic acid test & Brownish precipitate & +++ & + \\
\hline & Wagner's test & Yellow precipitate & +++ & + \\
\hline \multirow[t]{2}{*}{ Saponins } & Foam or Froth test & Persistent foam & ++ & +++ \\
\hline & Haemolysis test & $\begin{array}{l}\text { Haemolysis of red blood } \\
\text { cells }\end{array}$ & ++ & +++ \\
\hline Sterols & Salkowaski test & $\begin{array}{l}\text { Red color in Chloroform } \\
\text { layer }\end{array}$ & ----- & +++ \\
\hline Steroids & Liebarman-Buchard test & Deep green color & ----- & +++ \\
\hline Terpenoids & Acetic Anhydride + Conc. $\mathrm{H}_{2} \mathrm{SO}_{4}$ & Deep red color & + & ++ \\
\hline \multirow[t]{2}{*}{ Phenol/Tannins } & Ferric Chloride $\left(5 \% \mathrm{FeCl}_{3}\right)$ test & $\begin{array}{l}\text { Blue-black, green or } \\
\text { blue-green }\end{array}$ & + & ++ \\
\hline & Lead acetate test & White precipitate & + & +++ \\
\hline \multirow[t]{2}{*}{ Flavonoids } & & & & \\
\hline & Shinoda test & Pink color & + & +++ \\
\hline Anthocyanins & $\begin{array}{l}\text { Warmed \& cooled Aqueous solution }+ \\
20 \% \mathrm{HCl}+\mathrm{NH}_{4} \mathrm{OH}\end{array}$ & Pinkish red to Bluish red & ++ & ----- \\
\hline Coumarins & $\begin{array}{l}\text { Warmed \& cooled Aqueous solution + } \\
10 \% \mathrm{NaOH} \text { solution }\end{array}$ & Yellow color formation & +++ & + \\
\hline Glycosides & $\begin{array}{l}\text { Reaction of Aqueous solution with } 20 \% \\
\mathrm{NaOH} \text { solution }\end{array}$ & Yellow color formation & ----- & ++ \\
\hline
\end{tabular}

RBME and SBME: Root Bark and Stem Bark Methanol Extracts respectively

+++ : Present in high concentration, ++: Present in moderate concentration, + : Present in low concentration and ---:

Absent

Results of preliminary chemical screening revealed, in general, that stem bark methanol extract (SBME) is richer in bioactive phytochemical compounds than root bark methanol extract (RBME) as shown in Table 1. Ghosh [22] reported that Alkaloids, Saponins, Phenols, Tannins, Terpenoids and Flavonoids in general are known to have activities against pathogens and therefore aid the antimicrobial activities of medicinal plants through various mechanisms. Yenjai [23] reported Flavonoids as exerting many biological effects including antimicrobial activity.

\subsection{Antibacterial screening}

Results of antibacterial screening of the stem and root bark extracts of Urtica massaica were measured in terms of zones of inhibition, MIC and MBC. Among the tested bacteria, only three of them (two gram-negative: Escherichia coli, Salmonella sp, and one gram-positive: Staphylococcus aureus) were significantly sensitive to the plant extracts (RBME and SBME) with inhibition zone values greater than $7 \mathrm{~mm}$ as described by Clinical Laboratory Standards Institute [15]. Osuntokun and co-workers reported that the resistance of Gram-negative bacteria towards antibiotic agents might relatively be caused by the hydrophilic surface of their outer membrane rich in lipopolysaccharides molecules, posing barrier to the penetration of numerous antibiotic compounds [24, 2526].
This study revealed that the stem and root bark extracts, at different concentrations, exhibited various antibacterial activities against the susceptible tested strains (Table 2 and 3). Against E. coli, SBME at concentrations 150, 300 and $600 \mathrm{mg} / \mathrm{mL}$ exhibited higher inhibitory effect with average inhibition zones ranging from $21.667 \pm 1.529$ to $28.000 \pm 2.851 \mathrm{~mm}$ while RBME at similar concentrations showed lower inhibitory ability with average inhibition zones ranging from $19.667 \pm 1.734$ to $25.667 \pm 1.023 \mathrm{~mm}$. In the case of Salmonella sp, SBME at $150 \mathrm{mg} / \mathrm{mL}$ concentration showed no inhibition while at concentrations 300 and $600 \mathrm{mg} / \mathrm{mL}$ it exhibited inhibitory effect with $7.167 \pm 0.208$, and $24.067 \pm 2.503 \mathrm{~mm}$ respectively. Moreover, Salmonella sp manifested its resistance to RBME at all investigated concentrations. The positive control, Ciprofloxacin ( $5 \mu \mathrm{g} / \mathrm{Disc})$, inhibited the growth of Salmonella sp and E. coli with $30.000 \pm 0.000 \mathrm{~mm}$ zone of inhibition (Table 1).

In this study the standard antibiotic disc,

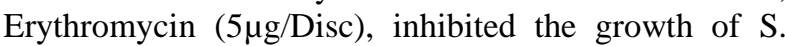
aureus in solid growth medium with $29.667 \pm 0.334 \mathrm{~mm}$ zone of inhibition. However, SBME, at concentrations 150,300 and $600 \mathrm{mg} / \mathrm{mL}$, showed inhibitory effect against the growth of $\mathrm{S}$. aureus with zones of inhibition ranging from $17.333 \pm 1.335$ to $21.667 \pm 0.334 \mathrm{~mm}$ respectively (Table 1). In the same vein, RBME exhibited lower inhibition against $\mathrm{S}$. aureus with range 
of inhibition zones from $15.000 \pm 0.578$ to $20.667 \pm 0.334$ $\mathrm{mm}$ (Table 1). The study showed that U. massaica stem bark (SBME) has greater antibacterial potential than root bark (RBME). This might be attributed to higher concentration of bioactive secondary metabolites present in the stem bark methanol extract (SBME).

According to American Society for Microbiology [17] and a research study carried out at University Sidi Mohamed, Morocco by Mounyr [16], only bacterial strains inhibited, in agar disk diffusion assay, by the plant extracts with inhibition zone greater or equal to $7 \mathrm{~mm}$ were further investigated for the determination of concentrations, MIC and MBC $(\mathrm{mg} / \mathrm{mL})$ as shown in Table 2 and 3 respectively.

The more sensitive/susceptible the bacterium is; the lower is the concentration of the extract required for inhibiting the growth of the test microbial organisms [16]. MIC values of SBME (Table 2) were 6.250 \pm 1.562 $\mathrm{mg} / \mathrm{mL}$ against E. coli, $10.156 \pm 4.752 \mathrm{mg} / \mathrm{mL}$ against Salmonella sp and $6.250 \pm 1.563 \mathrm{mg} / \mathrm{mL}$ against $\mathrm{S}$. aureus). Although, RBME was found inactive against Salmonella sp as in Agar disc diffusion method, its MIC values obtained were $7.813 \pm 1.563 \mathrm{mg} / \mathrm{mL}$ against $\mathrm{E}$. coli and $7.813 \pm 1.563 \mathrm{mg} / \mathrm{mL} \mathrm{S}$. aureus (Table 3). Furthermore, MBC values obtained were 12.500 \pm 3.125 $\mathrm{mg} / \mathrm{mL}$ for SBME against E. coli, 19.531 \pm 10.156 $\mathrm{mg} / \mathrm{mL}$ for SBME against Salmonella spp and $12.500 \pm 3.125 \mathrm{mg} / \mathrm{mL}$ for SBME against $\mathrm{S}$. aureus. But RBME exhibited the same MBC value, 15.625 \pm 3.125 $\mathrm{mg} / \mathrm{mL}$, against both $\mathrm{E}$. coli and $\mathrm{S}$. aureus while it proved ineffective against Salmonella $\mathrm{sp}$ as it was similarly found in Broth Macro-Dilution Method for MIC investigation (Table 3).

In this study, MIC and MBC values of RBME were lower than those of SBME against all sensitive tested micro-organisms. This might be attributed to the higher content of secondary metabolites present in SBME than in RBME. It is believed that bioactive compounds contributed to the observed antimicrobial activity of the selected medicinal plant parts because Mbata [27] stated that tannins and phenols possess antibacterial activities.

The findings indicated greater antimicrobial activities of stem bark than root bark of the studied plant, Urtica massaica. These findings are consistent with the findings of Dorota [28] who found that for Urtica plants, (U. plaviflora and U. dioica), the stem barks in n-butanol and methanol showed greater antimicrobial activities than the root barks.

This study revealed that the values of inhibition zones of plant extracts against susceptible tested strains were inversely proportional to their MIC and MBC values. This suggests the reproducibility of the experiments and the consistent potency of antimicrobial activities against the susceptible test bacteria.

Table-2: Antimicrobial activities (in terms of Inhibition zone values in mm) of U. massaica extracts against tested bacteria (by Agar disc diffusion method)

\begin{tabular}{|c|c|c|c|c|c|}
\hline & & \multicolumn{3}{|c|}{ Zone of inhibition (mm) } & \\
\hline \multirow[t]{2}{*}{ Bacteria } & Extract & at $150 \mathrm{mg} / \mathrm{ml}$ & at $300 \mathrm{mg} / \mathrm{ml}$ & at $600 \mathrm{mg} / \mathrm{ml}$ & +control \\
\hline & SBME & $21.667 \pm 1.529$ & $23.000 \pm 1.203$ & $28.000 \pm 2.851$ & \multirow[b]{3}{*}{$30.000 \pm 0.000$} \\
\hline \multirow{3}{*}{$\begin{array}{l}\text { Escherichia } \\
\text { coli }\end{array}$} & RBME & $19.667 \pm 1.734$ & $23.667 \pm 2.030$ & $25.667 \pm 1.023$ & \\
\hline & $\begin{array}{l}\text { Ciprofloxacin } \\
(5 \mu \mathrm{g} / \mathrm{Disc})\end{array}$ & - & - & - & \\
\hline & SBME & $\mathrm{N} \mathrm{S}$ & $7.167 \pm 0.208$ & $24.067 \pm 2.503$ & \multirow[b]{3}{*}{$30.000 \pm 0.000$} \\
\hline \multirow[t]{3}{*}{ Salmonella sp } & RBME & $\mathrm{N} \mathrm{S}$ & N S & N S & \\
\hline & $\begin{array}{l}\text { Ciprofloxacin } \\
(5 \mu \mathrm{g} / \mathrm{Disc})\end{array}$ & - & - & - & \\
\hline & SBME & $17.333 \pm 1.335$ & $19.000 \pm 0.578$ & $21.667 \pm 0.334$ & \multirow[b]{3}{*}{$29.667 \pm 0.334$} \\
\hline \multirow[t]{2}{*}{ S. aureus } & RBME & $15.000 \pm 0.578$ & $17.000 \pm 0.578$ & $20.667 \pm 0.334$ & \\
\hline & $\begin{array}{l}\text { Erythromycin } \\
\text { (15ug/Disc) }\end{array}$ & (1) & 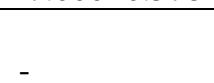 & - & \\
\hline
\end{tabular}

Each value is the average of 3 replicates \pm SEM $(\mathrm{n}=3)$. N S: Not sensitive to plant extracts (RBME and SBME) where RBME and SBME: Root Bark and Stem
Bark Methanol Extracts respectively. +Control: Positive

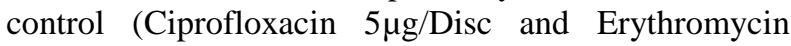
$15 \mu \mathrm{g} / \mathrm{Disc})$. 
Table-3: Antimicrobial activities (MIC and MBC in $\mathrm{mg} / \mathrm{mL}$ ) of $\mathrm{U}$. massaica extracts against tested bacteria (using Broth Macro-Dilution method and Sub-culturing method respectively)

\begin{tabular}{|l|l|l|l|l|}
\hline \multicolumn{5}{|l|}{ Test Bacterial organisms } \\
\hline Plant Extracts & Concentration of extracts & E. coli & Salmonella sp & S. aureus \\
\hline SBME & MIC $(\mathrm{mg} / \mathrm{mL})$ & $6.250 \pm 1.562$ & $10.156 \pm 4.752$ & $6.250 \pm 1.563$ \\
\hline & MBC $(\mathrm{mg} / \mathrm{mL})$ & $12.500 \pm 3.125$ & $19.531 \pm 10.156$ & $12.500 \pm 3.125$ \\
\hline RMBE & MIC $(\mathrm{mg} / \mathrm{mL})$ & $7.813 \pm 1.563$ & N S & $7.813 \pm 1.563$ \\
\hline & MBC $(\mathrm{mg} / \mathrm{mL})$ & $15.625 \pm 3.125$ & N S & $15.625 \pm 3.125$ \\
\hline
\end{tabular}

Each value is the average of 3 replicates \pm SEM (Mean \pm SEM). N S: Not sensitive to plant extracts (RBME and SBME) where RBME and SBME: Root Bark and Stem Bark Methanol Extracts respectively.

\section{Conclusion}

It is concluded from this study that Urtica massaica plays an important role in the treatment of different microbial infectious diseases in Rwanda and this is because the chemical compositions of its parts used are active against microorganisms that cause diseases. Our findings relatively provide a scientific support for the traditional use of Urtica massaica stem and root barks as treatment for ailments caused by bacterial pathogens.

Further bioactivity guided studies and in vitro/in vivo bioassays of antimicrobial activity along with toxicity studies are needed for fractionation, isolation and characterization of bioactive compounds present in both stem and roots of this Rwandan Urtica massaica before it is used for commercialization in the form of pharmaceutical medicine. However, more solvents should be used to extract the plant prior to determining other compositions and concentration of chemical components of the plant, and more tested organisms should be used for the antimicrobial activities.

\section{ACKNOWLEDGEMENT}

This study was funded by the grants from Pan African University Life and Earth Sciences/University of Ibadan, Nigeria. The authors wish to express their appreciations to all the technical staff of both the Department of Pathology/Bacteriology Laboratory/Clinical Training and Research at Centre Hospitalier Universitaire de Butare (CHUB) and Department of Pharmacy, College of Medicine and Health Sciences, University of Rwanda, Rwanda.

\section{REFERENCES}

1. World Health Organisation. (2002). WHO traditional medicine strategy 2002-2005 Geneva: World Health Organizatio, 677-684.

2. Bellamy, R. (Ed.). (2004). Susceptibility to infectious diseases: the importance of host genetics (No. 4). Cambridge University Press.
3. Centers for Disease Control and Prevention. (2011). A CDC framework for preventing infectious diseases. Sustaining the essentials and innovating for the future. Centers for Disease Control and Prevention, Atlanta.

4. Acharyya, S., Patra, A., \& Bag, P. K. (2009). Evaluation of the antimicrobial activity of some medicinal plants against enteric bacteria with particular reference to multi-drug resistant Vibrio cholerae. Tropical Journal of Pharmaceutical Research, 8(3).

5. Mandell, G.L., Douglas, R.G., Bennett, J.E. (2005). Principles and practice of infectious diseases, $6^{\text {th }}$ (ed.) An Imprint of Elsevier, USA, Churchill Livingstone.

6. Dyubeni, L., \& Buwa, L. V. (2012). An ethnobotanical study of plants used for the treatment of ear, nose and throat (ENT) infections in Nkonkobe Municipality, South Africa. Journal of Medicinal Plants Research, 6(14), 2721-2726.

7. Maroyi, A. (2013). Traditional use of medicinal plants in south-central Zimbabwe: review and perspectives. Journal of ethnobiology and ethnomedicine, 9(1), 1-18.

8. Van, N.D., Tap, N. (2008). An overview of the use of plants and animals in traditional medicine systems in Viet Nam. A Traffic South East Asia report. Ha Noi, Viet Nam, 16.

9. Rwangabo, P.C. (1993). La medicine Traditionnelle au Rwanda. KARTHALA Editions, Ethno-botany. Available online: https://books.google.com.ng/books (Accessed on the $9^{\text {th }}$ April, 2019 at 07:07pm); 1:77-90.

10. Alphonse, N. (2008). Chemical study of the stems of Urtica massaica, a medicinal plant eaten by mountain gorillas (Gorilla beringei beringei) in Park National des Volcans, Rwanda. Research Journal of Applied Sciences, 3(7):514-20.

11. Alsan, M. M., Westerhaus, M., Herce, M., Nakashima, K., \& Farmer, P. E. (2011). Poverty, global health, and infectious disease: lessons from Haiti and Rwanda. Infectious Disease Clinics, 25(3), 611-622.

12. Devmurari, V. P. (2010). Phytochemical screening study and antibacterial evaluation of Symplocos racemosa Roxb. Archives of applied science research, 2(1), 354-359.

13. Evans, W.C. (2002). Trease \& Evans, Pharmacognosy, $15^{\text {th }}$ edn. W.R. Saunder, London. 
14. Sofowora, A. (1996). Medicinal plants and traditional medicine in Africa. Karthala.

15. Clinical Laboratory Standards Institute. (2006). Performance standards for antimicrobial disk susceptibility tests, Approved standard $9^{\text {th }}$ ed. CLSI document M2-A9. 26:1. Clinical Laboratory Standards Institute, Wayne, PA., 56-60.

16. Balouiri, M., Sadiki, M., \& Ibnsouda, S. K. (2016). Methods for in vitro evaluating antimicrobial activity: A review. Journal of pharmaceutical analysis, 6(2), 71-79.

17. Hudzicki, J. (2009). Kirby-Bauer disk diffusion susceptibility test protocol.

18. Kassa, F. (2016). Evaluation of the Antimicrobial Activity Of $80 \%$ Methanol Extract and Solvent Fractions of the Leaves of Urtica Simensis Hochst. Ex. A. Rich.(Urticaceae) (Doctoral dissertation, Addis Ababa University).

19. Jorgensen, J. H., \& Turnidge, J. D. (2015). Susceptibility test methods: dilution and disk diffusion methods. Manual of clinical microbiology, 1253-1273.

20. Espina, L., Somolinos, M., Lorán, S., Conchello, P., García, D., \& Pagán, R. (2011). Chemical composition of commercial citrus fruit essential oils and evaluation of their antimicrobial activity acting alone or in combined processes. Food control, 22(6), 896-902.

21. Chittur, M. A. I., \& Gunjan, M. (2012). ANTIMICROBIAL ACTIVITY OF TINOSPORA CRISPA ROOT EXTRACTS. International Journal of Research in Ayurveda \& Pharmacy, 3(3).

22. Ghosh, P., Mandal, A., Chakraborty, P., Rasul, M. G., Chakraborty, M., \& Saha, A. (2010).
Triterpenoids from Psidium guajava with biocidal activity. Indian journal of pharmaceutical sciences, 72(4), 504.

23. Yenjai, C., Prasanphen, K., Daodee, S., Wongpanich, V., \& Kittakoop, P. (2004). Bioactive flavonoids from Kaempferia parviflora. Fitoterapia, 75(1), 89-92.

24. Sawer, I. K., Berry, M. I., \& Ford, J. L. (1997). Effect of medium composition, agitation and the presence of EDTA on the antimicrobial activity of cryptolepine. Letters in applied microbiology, 25(3), 207-211.

25. Gao, Y., van Belkum, M. J., \& Stiles, M. E. (1999). The outer membrane of Gram-negative bacteria inhibits antibacterial activity of brochocinC. Applied and Environmental Microbiology, 65(10), 4329-4333.

26. Temitope, O. O., Ajayi, A. O., Olorunnipa, T. A., Thonda, O. A., \& Taiwo, O. V. (2016). Phytochemical screening and antimicrobial properties of partially purified ethyl acetate extracts of Erythrina senegalensis leaf and bark against selected clinical isolates. Journal of Medicinal Plants, 4(3), 259-269.

27. Mbata, T. I., Debiao, L. U., \& Saikia, A. (2008). Antibacterial activity of the crude extract of Chinese green tea (Camellia sinensis) on Listeria monocytogenes. African journal of Biotechnology, 7(10).

28. Kregiel, D., Pawlikowska, E., \& Antolak, H. (2018). Urtica spp.: Ordinary plants with extraordinary properties. Molecules, 23(7), 1664.

Cite This Article: Maniriho O et al (2021). Chemical Screening and Antimicrobial Activities of Rwandan traditional medicinal plant, Urtica massaica Mildbr (Urticaceae). EAS J Pharm Pharmacol, 3(2), 56-63. 